Notes and Comments

\title{
Hydric and saline stress on Phaseolus lunatus L. seeds
}

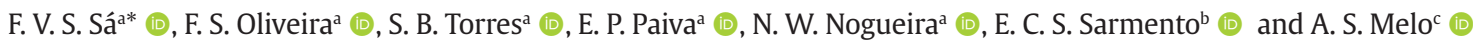 \\ a Universidade Federal do Semi-Árido - UFERSA, Centro de Ciências Agrárias, Mossoró, RN, Brasil \\ 'Universidade Federal do Ceará - UFC, Departamento de Fitotecnia, Fortaleza, CE, Brasil \\ c Universidade Estadual da Paraíba - UEPB, Departamento de Ciências Biológicas, Campina Grande, PB, Brasil
}

The Phaseolus lunatus L. is one of the most important legume crops of tropical regions worldwide, and in northeastern Brazil, where the bean is commonly known as 'feijão-fava', the species is both economically and socially important, owing to its ability to tolerate arid conditions, high temperatures, low and erratic rainfall, low-fertility soil, and high salinity (Nascimento et al., 2017). Indeed, drought and salinity are the primary factors that limit the germination of many crop species in arid and semi-arid regions (Patanè et al., 2013). Several studies have investigated the effects of water and salt stress in order to better understand the responses and factors (e.g., salt toxicity or PEG-6000-induced osmotic stress) that reduce seed germination (Patanè et al., 2013; Sá et al., 2017; Paiva et al., 2018). However, little is known about the effects of such stresses on the germination of $P$. lunatus seeds. Therefore, the present study, which was conducted in the laboratory (Universidade Federal Rural do Semi-Árido - UFERSA) with seeds from two traditional P. lunatus varieties ('Cara Larga' and 'Branquinha'), aimed to assess the tolerance of germination of $P$. lunatus seeds to water and salt stress.

Salt and water stress conditions were induced using $\mathrm{NaCl}$ and polyethylene PEG-6000, at the following osmotic potentials: $-0.3 \mathrm{MPa},-0.6 \mathrm{MPa}$, or $0.0 \mathrm{MPa}$ (control, distilled water). The $\mathrm{NaCl}$ saline solutions were prepared according to the Van't Hoff equation and corresponded to electrical conductivities of 8.33 and $16.67 \mathrm{dS} \mathrm{m}^{-1}$, respectively, and the PEG-6000 solutions were prepared according to Villela et al. (1991). The seeds were put on a roll with three Germitest ${ }^{\circledR}$ paper, moistened with the solutions in a volume equivalent to 2.5 times its weight, and then placed to germinate in a bioclimatic chamber, where moisture was constant (90\%), temperature was set at $25{ }^{\circ} \mathrm{C}$ under photoperiod of $8 \mathrm{~h}$ light/16 h dark.

After $4 \mathrm{~d}$ of incubation, the number of seeds with root protrusion of $2 \mathrm{~mm}$ were counted, i.e., first count of germination (GFC), and on the $8^{\text {th }}$ day the total number of germinated seeds was counted (G\%), values were expressed as a percentage (Brasil, 2009). At the end of the germination test, the shoot length (SL) and primary root length (RL) of normal plantlets from each replicate were measured. To determine the total dry matter (TDM) of the plantlets, samples were placed in Kraft paper bags, dried in a forced air circulation oven at $65{ }^{\circ} \mathrm{C}$ until achieving constant weight, and weighed using an analytical scale.

The study was conducted in a completely randomized design, and treatments were arranged in a $3 \times 2 \times 2$ factorial (osmotic potentials, varieties, and osmotic agents), with four replicates of 50 seeds. The obtained data were subjected to analysis of variance by $\mathrm{F}$ test $(\mathrm{p}<0.05)$, Student's t-test $(\mathrm{p}<0.05)$ for the factors cultivar and osmotic agents, and Dunnett's test $(\mathrm{p}<0.05)$ for the osmotic potentials.

The interaction between varieties, osmotic agents, and osmotic potentials was significant ( $\mathrm{p}<0.001$ ) for $\mathrm{GFC}, \mathrm{G} \%$, SL, and RL. For TDM, both variety $(\mathrm{p}<0.01)$ and osmotic potential treatment $(\mathrm{p}<0.05)$ had significant effects. The 'Branquinha' seeds subjected to a potential of -0.6 MPa, induced by PEG-6000, exhibited only $4 \%$ germination in the GFC but exhibited 75\% germination at the second count (G\%; Table 1). Meanwhile, 'Cara Larga' seeds placed under the same conditions exhibited $12 \%$ in the GFC and only $48 \%$ of $\mathrm{G} \%$ (Table 1 ). Reduction in the osmotic potential, due to either saline or water stress in the imbibition medium, can reduce the percentage and speed of seed germination and, in more severe cases, inhibit it, or even induce secondary dormancy (Bewley et al., 2013).

In regards to initial growth, salt stress $(\mathrm{NaCl})$ failed to affect either the SL or RL of the 'Cara Larga' plantlets (Table 1) but reduced both SL and RL of the 'Branquinha' plantlets, which indicated that that 'Branquinha' plants are sensitive to salinity during initial growth. In contrast, osmotic potentials of -0.3 and $-0.6 \mathrm{MPa}$, induced by PEG6000 (water stress), drastically reduced both the SL and RL of the 'Cara Larga' plantlets. At the osmotic potential of $-0.3 \mathrm{MPa}$, the 'Branquinha' plantlets were less affected by water stress than the 'Cara Larga' plantlets but exhibited similar responses at $-0.6 \mathrm{MPa}$ (Table 1 ). Reduction of growth is one of the most evident effects of salt stress on plants because, when they absorb water, they concomitantly absorb $\mathrm{Na}^{+}$and $\mathrm{Cl}^{-}$ions, which cause damage to membranes and inactivation of biogeochemical sites and consumption of reserves (Sá et al., 2017; Stefanello et al., 2020).

The TDM of the 'Cara Larga' plantlets was greater than that of the 'Branquinha' plantlets (Figure 1A), and the TDM of plantlets grown from seeds germinated at

*e-mail: vanies_agronomia@hotmail.com

Received: January 30, 2020 - Accepted: November 17, 2020 
Table 1. Germination first count (GFC) and germination percentage (G\%), shoot length (SL) and primary root length (RL) of $P$. lunatus seeds subjected to different osmotic agents and potentials.

\begin{tabular}{|c|c|c|c|c|c|}
\hline \multirow{2}{*}{ Osmotic agents } & \multirow{2}{*}{$\begin{array}{l}\text { Osmotic potentials } \\
\text { (MPa) }\end{array}$} & 'Cara Larga' & 'Branquinha' & 'Cara Larga' & 'Branquinha' \\
\hline & & \multicolumn{2}{|c|}{ GFC (\%) } & \multicolumn{2}{|c|}{ G\% } \\
\hline \multirow{3}{*}{$\mathrm{NaCl}$} & 0.0 (control) & $86 \mathrm{aBX}$ & $98 \mathrm{aAX}$ & $97 \mathrm{aAX}$ & $99 \mathrm{aAX}$ \\
\hline & -0.3 & $95 \mathrm{aAX}$ & $99 \mathrm{aAX}$ & $95 \mathrm{aAX}$ & $99 \mathrm{aAX}$ \\
\hline & -0.6 & $87 \mathrm{aBX}$ & $100 \mathrm{aAX}$ & $88 \mathrm{aBX}$ & $100 \mathrm{aAX}$ \\
\hline \multirow{3}{*}{ PEG-6000 } & 0.0 (control) & $86 \mathrm{aBX}$ & $98 \mathrm{aAX}$ & $97 \mathrm{aAX}$ & $99 \mathrm{aAX}$ \\
\hline & -0.3 & $37 \mathrm{bBY}$ & $49 \mathrm{bAY}$ & $62 \mathrm{bBY}$ & $93 \mathrm{bAX}$ \\
\hline & -0.6 & $12 \mathrm{bAY}$ & $4 \mathrm{bBY}$ & $48 \mathrm{bBY}$ & $75 \mathrm{bAY}$ \\
\hline \multirow[t]{2}{*}{ Osmotic agents } & Osmotic potentials (MPa) & $\mathrm{SL}(\mathrm{cm})$ & & $\mathrm{RL}(\mathrm{cm})$ & \\
\hline & 0.0 (control) & $2.12 \mathrm{aBX}$ & $3.64 \mathrm{aAX}$ & $5.36 \mathrm{aAX}$ & $5.54 \mathrm{aAX}$ \\
\hline \multirow[t]{3}{*}{$\mathrm{NaCl}$} & -0.3 & $2.72 \mathrm{aAX}$ & $1.67 \mathrm{bBX}$ & $4.65 \mathrm{aAX}$ & 4.17 bAX \\
\hline & -0.6 & $2.66 \mathrm{aAX}$ & $1.67 \mathrm{bBX}$ & $3.99 \mathrm{aAX}$ & $2.34 \mathrm{bBX}$ \\
\hline & 0.0 (control) & $2.12 \mathrm{aBX}$ & $3.64 \mathrm{aAX}$ & $5.36 \mathrm{aAX}$ & $5.54 \mathrm{aAX}$ \\
\hline \multirow[t]{2}{*}{ PEG-6000 } & -0.3 & $1.12 \mathrm{bBY}$ & $1.54 \mathrm{bAX}$ & $2.1 \mathrm{bBY}$ & $3.85 \mathrm{bAX}$ \\
\hline & -0.6 & $0.792 \mathrm{bAY}$ & $1.12 \mathrm{bAX}$ & $2.36 \mathrm{bAY}$ & $2.38 \mathrm{bAX}$ \\
\hline
\end{tabular}

Equal lowercase letters ( $a$ and $b$ ) in the column do not differ by Dunnett's test $(p \leq 0.05)$. Equal uppercase letters in the row ( $A$ and $B$ ) and in the column (X and Y) do not differ by Student's t-test ( $\mathrm{p} \leq 0.05)$.
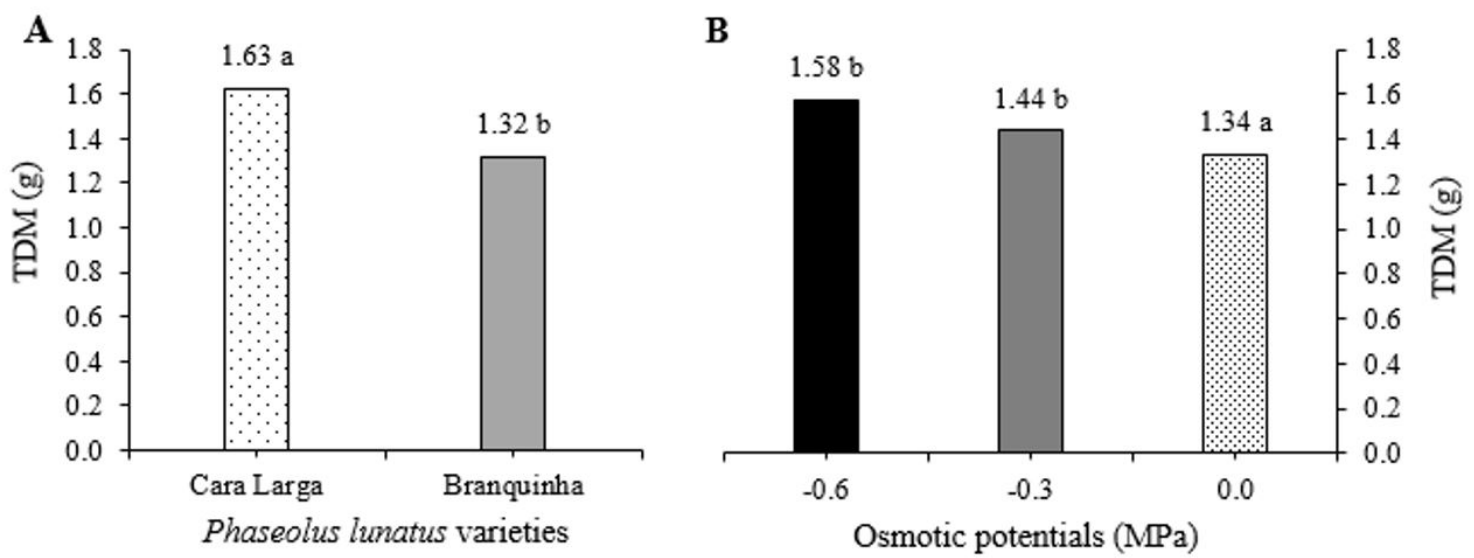

Figure 1. Total dry matter (TDM) of plantlets of two varieties of $P$. lunatus (Student's t-test, $\mathrm{p} \leq 0.05)(\mathrm{A})$ at three different osmotic potentials (Dunnett's test, $\mathrm{p} \leq 0.05)(\mathrm{B})$.

low osmotic potentials (- -0.3 and $-0.6 \mathrm{MPa})$ was greater than that of the plantlets grown from control seeds (Figure 1B). Inefficient hydration of seed tissues prevents the degradation of reserves, so that the weight of the maintained plantlet consists almost entirely of the dry seed weight; in this case, the cotyledons (Sá et al., 2017; Paiva et al., 2018).

In summary, the negative effects of PEG-6000 were more intense than those of $\mathrm{NaCl}$ in P. lunatus. The germination of both varieties of $P$. lunatus was not affected by salt stress $(\mathrm{NaCl},-0.6 \mathrm{MPa})$, but was drastically reduced by water stress (PEG-6000, - 0.3 MPA). The variety 'Cara Larga' is tolerant to salt stress and the variety 'Branquinha' is tolerant to water stress during the initial growth stage.

\section{References}

BEWLEY, J.D., BRADFORD, K.J., HILHORST, H.W.M. and NONOGAKI, H., 2013. Seeds: physiology of development, germination and dormancy. $3^{\text {rd }}$ ed. New York: Springer. 392 p. http://dx.doi. org/10.1007/978-1-4614-4693-4.

BRASIL. Ministério da agricultura e Reforma Agrária. Secretaria Nacional de Defesa Agropecuária, 2009. Regras para análise de sementes. Brasília: SNDA. 399 p.

NASCIMENTO, M.G.R., ALVES, E.U., SILVA, M.L.M. and RODRIGUES, C.M., 2017. Lima bean (Phaseolus lunatus L.) seeds exposed to different salt concentrations and temperatures. Revista Caatinga, vol. 30, no. 3, pp. 738-747. http://dx.doi.org/10.1590/1983-21252017v30n322rc.

PAIVA, E.P., SÁ, F.V.S., TORRES, S.B., BRITO, M.E.B., MOREIRA, R.C.L. and SILVA, L.A., 2018. Germination and tolerance of cowpea (Vigna unguiculata) cultivars to water stress. Revista Brasileira 
de Engenharia Agrícola e Ambiental, vol. 22, no. 6, pp. 407-411. http://dx.doi.org/10.1590/1807-1929/agriambi.v22n6p407-411.

PATANÈ, C., SAITA, A. and SORTINO, O., 2013. Comparative effects of salt and water stress on seed germination and early embryo growth in two cultivars of sweet sorghum. Journal Agronomy E Crop Science, vol. 199, no. 1, pp. 30-37. http:// dx.doi.org/10.1111/j.1439-037X.2012.00531.x.

SÁ, F.V.S., NASCIMENTO, R., PEREIRA, M.O., BORGES, V.E., GUIMARAES, R.F.B., RAMOS, J.G., MENDES, J.S. and PENHA, J.L., 2017. Vigor and tolerance of cowpea (Vigna unguiculata) genotypes under salt stress. Bioscience Journal, vol. 33, no. 6, pp. 1488-1494. http://dx.doi.org/10.14393/BJv33n6a2017-37053.

STEFANELLO, R., VIANA, B.B., GOERGEN, P.C.H., NEVES, L.A.S. and NUNES, U.R., 2020. Germination of chia seeds submitted to saline stress. Brazilian Journal of Biology = Revista Brasileira de Biologia, vol. 80, no. 2, pp. 285-289. http://dx.doi.org/10.1590/15196984.192140. PMid:31291400.

VILLELA, F.A., DONI FILHO, L. and SEQUEIRA, E.L., 1991. Tabela de potencial osmótico em função da concentração de polietileno glicol 6000 e da temperatura. Pesquisa Agropecuária Brasileira, vol. 26, no. 11-12, pp. 1957-1968. 